\title{
Ethical Considerations on Brain-Machine Interface
}

\author{
Kadircan H Keskinbora* \\ History of Medicine and Medical Ethics, Bahcesehir University, Turkey
}

Submission: June 11, 2018; Published: July 10, 2018

*Corresponding author: Kadircan H Keskinbora, History of Medicine and Medical Ethics, School of Medicine, Bahcesehir University, Istanbul, Turkey, Email: kadircan.keskinbora@gmail.com

Keywords: Ethical Considerations; Brain-Machine Interface; Wireless implants; Neural Dust; Depression;Dementia; Diseases and disorders Prosthetic limbs

\section{Introduction}

The wireless implants, so-called "Neural Dust" have the potential capabilities to spark the neurons in central nervous system or peripheral nervous system [1]. Such potentials can be utilized in various areas that could benefit from such technologies e.g., medical field, to hasten the progress and new future treatments developments for many diseases and disorders such as depression, dementia etc. [2]. Thus, neural dust triggered further researches to expand and increase the potential usage for these technologies in order to utilize them in brain-machine interface which will enable humans in controlling prosthetic limbs or exoskeleton to enhance normal human capabilities.

Such applications of technologies provoked ethical considerations because of its violations ethical principles in medicine and other areas and because of the possibilities of usage in mischievous way as in "mind control", since neural dust works by stimulating brain cells through "electroceutical" or waves that alter brain mechanism. This possibility would demolish the principle of autonomy and self-determination.

The nervous system composed of specialized cells called neurons which communicate and convey information in form of electric signals through dendritic process and then send these electric signals to the end-target that could be gland or muscle and thus stimulate the end-target organ to function. Unfortunately, the characteristics and properties of the nervous system neurons impose restrictions to on the cells to regenerate and heal after injuries or impairment therefore, any damage to the nervous system can lead to permanent disability and deficits.

However, the progression and advances in bioengineering fields permit us to manipulate the signals inside the brain through small devices called motes or dust which lead to improvements and breakthroughs in rehabilitation and therapies of neurological deficits including voluntary actions and cognition.

The first attempt to manipulate this system was made in 1960s which was the first endeavor to treat hear loss through cochlear electrode implant that convey signals to cochlear nerve which is responsible for transmission of auditory information to the brain [3]. This attempt subsequently lead to further attempts and researched that open a window for further possibilities to treat other disorders through brain implants which is called "cranial pacemakers" or "deep brain stimuli-DBS" that could stimulate the brain neurons and modulate the electricity in impaired brain activity and thus be utilized as a therapeutic tool used in treatment of epilepsy or any other disorders and disease that associated with altered brain signals.

However, the technologies and brain implants raise serious ethical considerations as they are threatening the principles and codes of ethics that the field of medicine is working accordingly [4]. The brain implants and methods are being considered to be applied on soldiers with post-traumatic stress disorders through a process of memory deletion or brain remodeling to handle the suicide predisposition [5]. Such method can prove to be more convenient than traditional psychotherapy sessions since these sessions expose the patients to those stressful memories which can exacerbate the situation [6]. In a way to get the best results for benefit of patients through utilitarian approach, it is needed to distinguish of what techniques and technologies can be made use as well as how to use them. People who have specific intellectual and moral characteristics may not be satisfied with such an approach. In fact, to understand the patient's values and goals, it is inevitable to take into consideration the asymmetries of knowledge and power 
in terms of medical relationship as well as considering the modern society's anti-paternatistic standing [7]. For example, the respect for autonomy of the patients which implies the individual capacity for making choices in accordance with his/her believes and values and live accordingly or in a bigger picture, it would suggest the possibilities of malicious usage such as mind control, inserting false memories [8,9] for manipulation purposes or building an army of enhanced abilities by making them more apathetic or physically more capable through exoskeletons.

Using neural dust therapies in treatment with the patients consent and awareness of the outcomes of this procedure is not the problem, however, the non-voluntary interventions on patients for experiences and mind control purposes are what bring the ethical dilemma. Or in another scenario, the patient might become addict by frequent stimulation of happiness center.

\section{Conclusion}

In conclusion, nanotechnology, brain implants and neural dust are breakthrough is science and pave a way for further developments of therapeutic methods to treat or at least manage diseases that previously was untreatable and improve the life quality of patients. However, the same technology can menace ethics. As it can violate the "respect for autonomy" principle, violation or privacy or misuse and abuse for manipulative or political purposes. It is safe to say that nanotechnology is a knife with two sharp edges.

\section{References}

1. Keskinbora KH, Keskinbora K (2018) Ethical considerations on novel neuronal interfaces. Neurological Sciences 39(4): 607-613.

2. Suthana N, Haneef Z, Stern J, Mukamel R, Behnke E, et al. (2012) Memory enhancement and deep-brain stimulation of the entorhinal area. N Engl J Med 366(6): 502-510.

3. Perlmutter JS, Mink JW (2006) Deep brain stimulation. Annu Rev Neurosci 29(2): 229-257.

4. Gerlai R (2003) Memory enhancement: the progress and our fears. Genes Brain Behav 2(2):187-190.

5. West N (2013) Mind control scientists find new memory manipulation technology.

6. Gerlai R (2003) Memory enhancement: the progress and our fears. Genes Brain Behav 2(2):187-190.

7. Jotterand F, Giordano J (2011) Transcranial Magnetic Stimulation, Deep Brain Stimulation, and Personal Identity Ethical Questions and Neuroethical Approaches for Medical Practice. In: Giordano J. ed. Neurotechnology: Premises, Potential, and Problems. Boca Raton: CRC Press 23(5):476-85.

8. Strout J (2017) Mind uploading home page.

9. Swan M (2016) The future of brain-computer interfaces: block chaining your way into a cloud mind. J Evol Technol 26(2). - October 2016.

\section{Your next submission with Juniper Publishers will reach you the below assets}

- Quality Editorial service

- Swift Peer Review

- Reprints availability

- E-prints Service

- Manuscript Podcast for convenient understanding

- Global attainment for your research

- Manuscript accessibility in different formats ( Pdf, E-pub, Full Text, Audio)

- Unceasing customer service

Track the below URL for one-step submission https://juniperpublishers.com/online-submission.php 